\title{
Past and present carbon accumulation and loss in Southeast Asian peatlands
}

Sue PAGE ${ }^{1}$, R. Wüst ${ }^{2}$ AND C. BANKs ${ }^{1,3}$

'Department of Geography, University of Leicester, UK; sep5@le.ac.uk

${ }^{2}$ School of Earth and Environmental Sciences, James Cook University, Townsville, Australia; ${ }^{3}$ National Oceanography Centre, University of Southampton, UK

\section{Tropical peatlands store $\sim 75 \mathrm{Pg}$ carbon and have operated as long-term net carbon sinks throughout the Holocene. However, intensive land development is destabilizing these reservoirs, resulting in large carbon emissions to the atmosphere and loss of valuable low-latitude peat paleorecords.}

\section{Location and carbon storage}

By area, peatlands have their greatest extent in the boreal and temperate zones (Immirzi et al., 1992) but tropical deposits, located in Southeast Asia, Africa, the Caribbean, and Central and South America, are also an important component of the global resource and terrestrial carbon (C) storage in both their above-ground biomass and underlying thick peat mass (Rieley et al., 1996; Page et al., 1999, 2004). A recent study (Page et al., submitted) indicates that tropical peatlands cover $\sim 439,238$ $\mathrm{km}^{2}(\sim 11 \%$ of global peatland area), with a peat $C$ pool of $88.5 \mathrm{Pg}(\sim 17-19 \%$ of the global peat C pool (Immirzi et al., 1992)). Globally, the most important tropical peatlands occur in Southeast Asia $57 \%$ of total area; $68.5 \mathrm{Pg}$ of $\mathrm{C}$, representing $77 \%$ of global tropical peatland carbon stores). In this region, Indonesia holds by far the largest share (57.4 Pg or $65 \%)$, followed by Malaysia (9.1 Pg or 10\%) (Fig. 1).

\section{Peatlands in Southeast Asia: types}

Most Southeast Asian peatlands are ombrotrophic (precipitation-fed), although a few basin peatlands are minerotrophic (receiving surface runoff and/or groundwater), and support a vegetation of dense swamp forest. A combination of low topographic relief, impermeable substrates and high effective rainfall have provided conditions suitable for slow decomposition of organic material and the accumulation of thick (often $>10 \mathrm{~m}$ ) deposits of woody peat.

Three categories of lowland peatlands have been proposed: (i) coastal, (ii) sub-coastal or valley, and (iii) high, interior or watershed (Rieley et al., 1996; Page et al., 1999, 2006). Coastal peatlands occur along maritime fringes and in deltaic areas where they have developed over marine sediments, inland of accreting mangrove and Nipa palm swamps (Anderson, 1983; Staub and Esterle, 1994). Sub-coastal peatlands are further inland at slightly higher elevations (5-15 m asl) where peat formation was initiated as a result of rising ground water levels, linked to

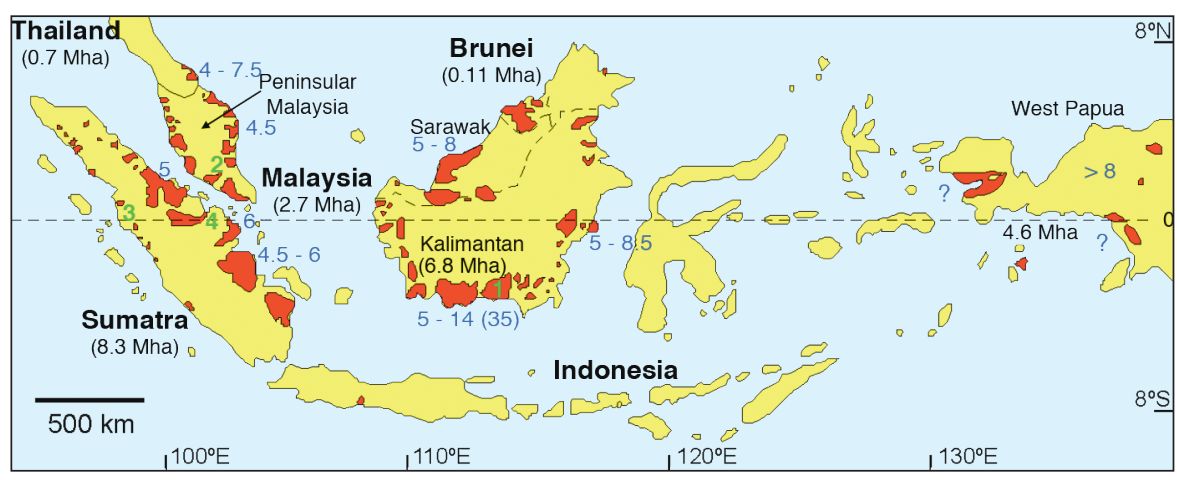

Figure 1: Distribution (red shading; in million ha, after Rieley et al., 1996) and approximate dates of initiation (blue numbers; cal ka BP) for peatland in Southeast Asia. Question marks indicate unknown peatland initiation age. Green numbers indicate the location of peatlands referred to in text: 1) Sungai Sebangau, 2) Tasek Bera, 3) Tao Sipinggan, and 4) Siak Kanan. changes in sea level. High peatlands have been described from Central Kalimantan (Indonesian Borneo; Fig. 1) up to $200 \mathrm{~km}$ inland from the coast, where they cover low-altitude, watershed positions (10$30 \mathrm{~m}$ asl) (Sieffermann et al., 1988, 1992; Page et al., 1999; Morley, 2000). In addition, some isolated basin deposits have formed in and around lakes (e.g., Anshari Dam et al., 2001; van der Kaars et al., 2001; Penny, 2001; Maxwell, 2001; Maxwell and Liu, 2002). et al., 2001, 2004; Wüst and Bustin, 2004;

\section{Peat and carbon accumulation}

Only a few peatlands in Southeast Asia have been investigated for peat structure, age, development, and rates of peat and C accumulation (e.g., Neuzil, 1997; Brady, 1997; Page et al., 2004; Wüst and Bustin, 2004), the onset and development of which range from the Late Pleistocene to the Holocene. Paleoenvironmental studies of peatlands in Borneo reveal initiation dates ranging from Late Pleistocene ( 40 ${ }^{14} \mathrm{C}$ ka BP) in Lake Sentarum basin, West Kalimantan (Anshari et al., 2001, 2004) to

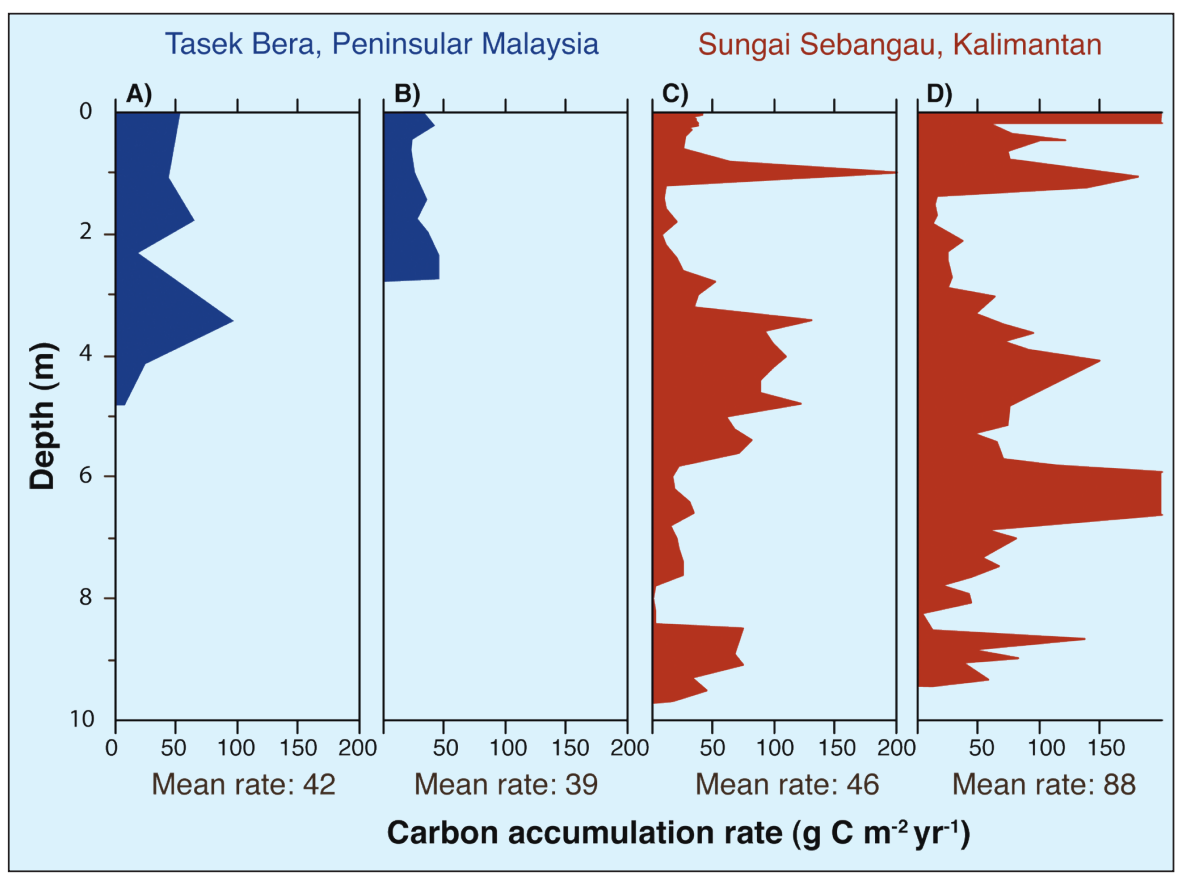

Figure 2: Carbon accumulation rate down-core for a minerotrophic peat on Peninsular Malaysia (Tasek Bera; $\boldsymbol{A}$ ) core B53, B) core B144) (Wüst and Bustin, 2004) and an ombrotrophic peat on Kalimantan (Sungai Sebangau; C) core SA6.5, D) core Kal1, located within $1.5 \mathrm{~km}$ of each other) (Page et al., 2004; Wüst unpub. data). 
$\sim 23{ }^{14} \mathrm{C}$ ka BP for high peat in Central Kalimantan (Page et al., 2004), to the early Holocene (10 - 8 cal ka BP) for other high and sub-coastal deposits (Neuzil, 1997; SiefferIn comparison, the extensive coastal deposits are the youngest peatlands in the region, with initiation around 3.5 - 6 cal ka BP (e.g., Anderson and Muller, 1975; Staub and Esterle, 1994).

A detailed record of peat accumulation from Central Kalimantan (Page et al., 2004) (Figs. 1, 2), reveals a relatively rapid initial rate of peat accumulation of $1 \mathrm{~mm}$ $\mathrm{a}^{-1}$ between $24-26 \mathrm{cal} \mathrm{ka} \mathrm{BP}\left(22-23{ }^{14} \mathrm{C}\right.$ ka $\mathrm{BP})$, equivalent to a $\mathrm{C}$ accumulation rate of $\sim 54 \mathrm{~g} \mathrm{C} \mathrm{m}^{-2} \mathrm{a}^{-1}$. This period probably lasted for several thousand years until the onset of the drier Last Glacial Maximum (LGM) ( $18{ }^{14} \mathrm{C}$ ka ago), when conditions were less favorable to peat formation. During and after the LGM, until 13 cal ka BP, peat and $C$ accumulation rates were low at only $0.04 \mathrm{~mm} \mathrm{a}^{-1}$ and $1.3 \mathrm{~g} \mathrm{C} \mathrm{m}^{-2} \mathrm{a}^{-1}$, respectively. The beginning of the Holocene, however, saw a rapid resurgence: between 8.54 and $7.82 \mathrm{cal} \mathrm{ka} \mathrm{BP}$ the peat accumulation rate increased from 0.60 to $2.55 \mathrm{~mm} \mathrm{a}^{-1}$ with an average $C$ accumulation rate of $92 \mathrm{~g} \mathrm{C} \mathrm{m}^{-2}$ mann et al., 1988; Staub and Esterle, 1994).

$\mathrm{a}^{-1}$ and the formation of more than $3.5 \mathrm{~m}$ of peat over a $\sim 2.2$ ka period ( $~ 9.1-6.9 \mathrm{cal}$ ka BP). Rapid sea-level rise at the end of the LGM led to the transgressive flooding of the Sunda and Sahul Shelves. Sea level changes were associated with warmer sea surface temperatures (Kienast et al., 2001, 2006), which likely resulted in increased precipitation, and the backing up of rivers owing to reduced drainage (Siefferman et al., 1987). In combination, these conditions favored peat accumulation in coastal areas with low topographic relief, such as along the seaboards of Borneo, Sumatra, E and W Peninsular Malaysia, and further inland in Borneo on interfluvial divides (Fig. 1; Wüst et al., 2007).

Towards the end of this period of rapid accumulation for inland high peats ( 6 cal ka BP), large, relatively flat areas of new coastal environments were being exposed throughout the Southeast Asian region as rising sea levels stabilized and fell slightly during the mid-Holocene (Geyh et al., 1979; Hu et al., 2003; Tjia, 1992; Tjia et al., 1984). The combination of favorable topographic and climatic conditions led to rapid peat accumulation across coastal lowlands (Wilford, 1959; Hesp et al., 1998;

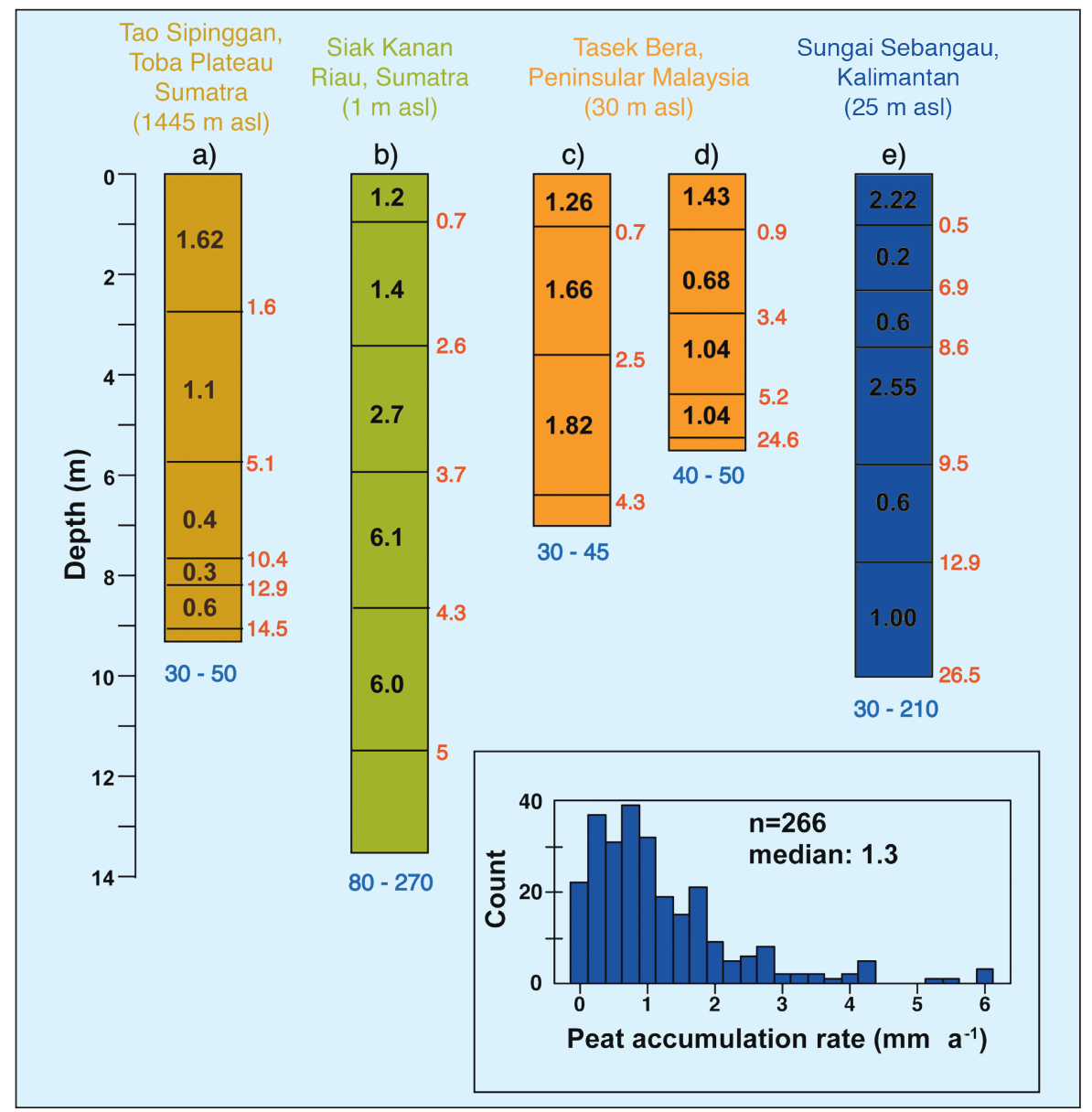

Figure 3: Selected peat sections from various sites in Sumatra $(\boldsymbol{a}, \boldsymbol{b})$, Peninsular Malaysia $(\boldsymbol{c}, \boldsymbol{d})$ and Kalimantan (e) showing approximate age of peat accumulation (cal ka BP, red numbers), peat accumulation rates ( $\mathrm{mm} \mathrm{a}^{-1}$, black numbers) and carbon accumulation rates ( $\mathrm{g} \mathrm{C} \mathrm{m}^{-2} \mathrm{a}^{-1}$, blue numbers); the latter vary between $30-270 \mathrm{~g} \mathrm{C} \mathrm{m}^{-2}$ $a^{-1}$. Data from Maloney and McCormac, 1995 (Tao Sipinggan); Neuzil, 1997 (Siak Kanan); Wüst and Bustin, 2004 (Tasek Bera); Page et al., 2004 (Sungai Sebangau). Inset: Histogram of peat accumulation rates of 266 samples across sites in Sumatra, West Java, Kalimantan, Sarawak, Peninsular Malaysia, Thailand, Sulawesi and New Guinea.
Staub and Esterle, 1994). In the Rajang Delta of Sarawak (Fig. 1), $4.45 \mathrm{~m}$ of peat accumulated between 6.4 and $2.06 \mathrm{cal}$ ka BP ( 1.26 $\mathrm{mm} \mathrm{a}^{-1}$; Staub and Esterle, 1994), whilst on the east coast of Sumatra, peatlands underwent very rapid accumulation with initial rates as high as $6-13 \mathrm{~mm} \mathrm{a}^{-1}$ between 5.3 - 4.3 cal ka BP (Neuzil, 1997). A study from inland Tasek Bera on Peninsular Malaysia (Wüst and Bustin, 2004) also indicates peat initiation at this time, with highest rates occurring after $4.3 \mathrm{cal}$ ka BP. The rapid accumulation of inland peats, subsequently followed by the formation of deep coastal peat deposits, must have provided a large regional sink for atmospheric carbon throughout the Holocene.

\section{From carbon sink to carbon source}

Radiocarbon dating of peat material from sites across Southeast Asia (Fig. 3) reveals a long-term median peat accumulation rate of $\sim 1.3 \mathrm{~mm} \mathrm{a}^{-1}$ (i.e., $67 \mathrm{~g} \mathrm{C} \mathrm{m}^{-2} \mathrm{a}^{-1}$ assuming a peat bulk density of 0.09 and $56 \%$ C content), which is about 2-10 times the rate for boreal and subarctic peatlands (0.2-0.8 $\mathrm{mm} \mathrm{a}^{-1}$ ) (Gorham, 1991). Currently, however, most, if not all, remaining peatlands in Southeast Asia are to some extent degraded with many no longer functioning as $\mathrm{C}$-accumulating systems. Anthropogenic activity is the principal cause of this shift, although longer-term climateinduced changes are also important in some locations (Page et al., 2004). Deforestation, drainage, large-scale conversion to plantation agriculture and regular fires have resulted in carbon flux to the atmosphere and loss of carbon sequestration function. Current $\mathrm{C}$ emissions are of the order $\sim 360 \mathrm{Mt} \mathrm{C} \mathrm{a}^{-1}\left(\sim 170 \mathrm{Mt} \mathrm{C} \mathrm{a}^{-1}\right.$ from drainage-related peat decomposition (Hooijer et al., 2006); $190 \mathrm{Mt} \mathrm{C} \mathrm{a}^{-1}$ from peat fires (Page et al., 2002; van der Werf et al., 2008)), equivalent to $4.5 \%$ of global emissions from fossil fuels.

Further detailed investigations of tropical peatland archives could result in new information about ENSO, monsoons and ITCZ migration, as well as an improved understanding of Holocene climate evolution in Southeast Asia and the long-term role of tropical peatlands in the regional and global C cycle. Unfortunately the opportunities to study these paleorecords are now being compromised by the rapid rate of peatland loss owing to human activities. 


\section{References}

Anshari, G., Kershaw, AP. and van der Kaars, S., 2001: A Late Pleistocene and Holocene pollen and charcoal record from peat swamp forest, Lake Sentarum Wildlife Reserve, West Kalimantan, Indonesia, Palaeogeography, Palaeodlimatology, Palaeoecology, 171 213-228

Page, S.E., Siegert, F., Rieley, J.0., Boehm, H.-D.V., Jaya, A. and Limin, S., 2002: The amount of carbon released from peat and forest fires in Indonesia during 1997, Nature, 420: 61-65.
Page, S.E., Wüst, R.A.J., Weiss, D., Rieley, J.0., Shotyk, W. and Limin, S.H 2004: A record of Late Pleistocene and Holocene carbon accumulation and climate change from an equatorial peat bog (Kalimantan, Indonesia): implications for past, present and future carbon dynamics, Journal of Quaternary Science, 19: 625-635.

Page, S.E., Rieley, J.0. and Wüst, R., 2006: Lowland tropical peatlands of Southeast Asia. In: Martini, P., Martinez-Cortizas, A. and Chesworth, W. (Eds) Peatlands: basin evolution and depository of records on global environmental and climatic changes, Elsevier, Amsterdam (Developments in Earth Surface Processes series). pp. $145-172$
Wüst, R.A.J. and Bustin, R.M., 2004: Late Pleistocene and Holocene development of the interior peat-accumulating basin of tropica Tasek Bera, Peninsular Malaysia, Palaeogeography, Palaeoclimatology, Palaeoecology, 211: 241-270.

For full references please consult:

http://www.pages-igbp.org/products/newsletters/ref2010_1.htm

\section{Inception, history and development of peatlands in the}

\section{Amazon Basin}

Outı Lähteenoja ${ }^{1}$ and Katherine H. Roucoux ${ }^{2}$

'Department of Biology, University of Turku, Finland; outi.lahteenoja@utu.fi

${ }^{2}$ School of Geography, University of Leeds, UK

The existence of peatlands in the Amazonian lowlands has only recently been confirmed, owing to the remoteness of the area. These peatlands are important for regional carbon cycling and habitat diversity, and represent valuable potential resources for paleoecological research.

\section{The Amazon's floodplain peatlands}

Amazonia, the world's largest continuous area of humid tropical lowland rainforest, is famous for its dense river network, large seasonal variations in water level (on average $10 \mathrm{~m}$ at Manaus, Brazil), and extensive floodplains and wetlands covered by Mauritia palms, floodplain forest or savanna-like vegetation (Irmler, 1977; Junk, 1983; Junk and Piedade, 2005; Keddy et al., 2009). Despite the great extent of wetlands within the Amazon Basin, the existence of tropical peatlands has rarely been considered (but see Suszczynski, 1984; Schulman et al., 1999; Ruokolainen et al., 2001; Guzmán Castillo, 2007). Two studies carried out recently in Peruvian lowland Amazonia (Loreto region, Fig. 1) by members of the Amazon Research Team of the University of Turku (Finland) reveal that peat deposits, up to $6 \mathrm{~m}$ thick, are widespread on floodplain wetlands of the Western Amazon Basin (Lähteenoja et al., 2009a, 2009b). Sixteen of seventeen studied wetland sites contained some kind of peat deposit. According to the very rough estimate of Schulman et al. (1999) based on local land-cover maps, satellite images, grey literature and sporadic field observations, Amazonian peatlands may cover up to $150000 \mathrm{~km}^{2}$, an area equivalent to half of Finland, and about $75 \%$ of the area covered by the better-known tropical peatlands of Indonesia (Rieley and Page, 2005; Page et al., this issue).

\section{History and development}

Since their late Holocene inception, the peatlands identified in Peruvian Amazonia have accumulated peat and carbon at relatively high rates $(0.94-4.88 \mathrm{~mm}$ per year, and $26-195 \mathrm{~g} \mathrm{C} \mathrm{m}^{-2}$ per year, respectively)

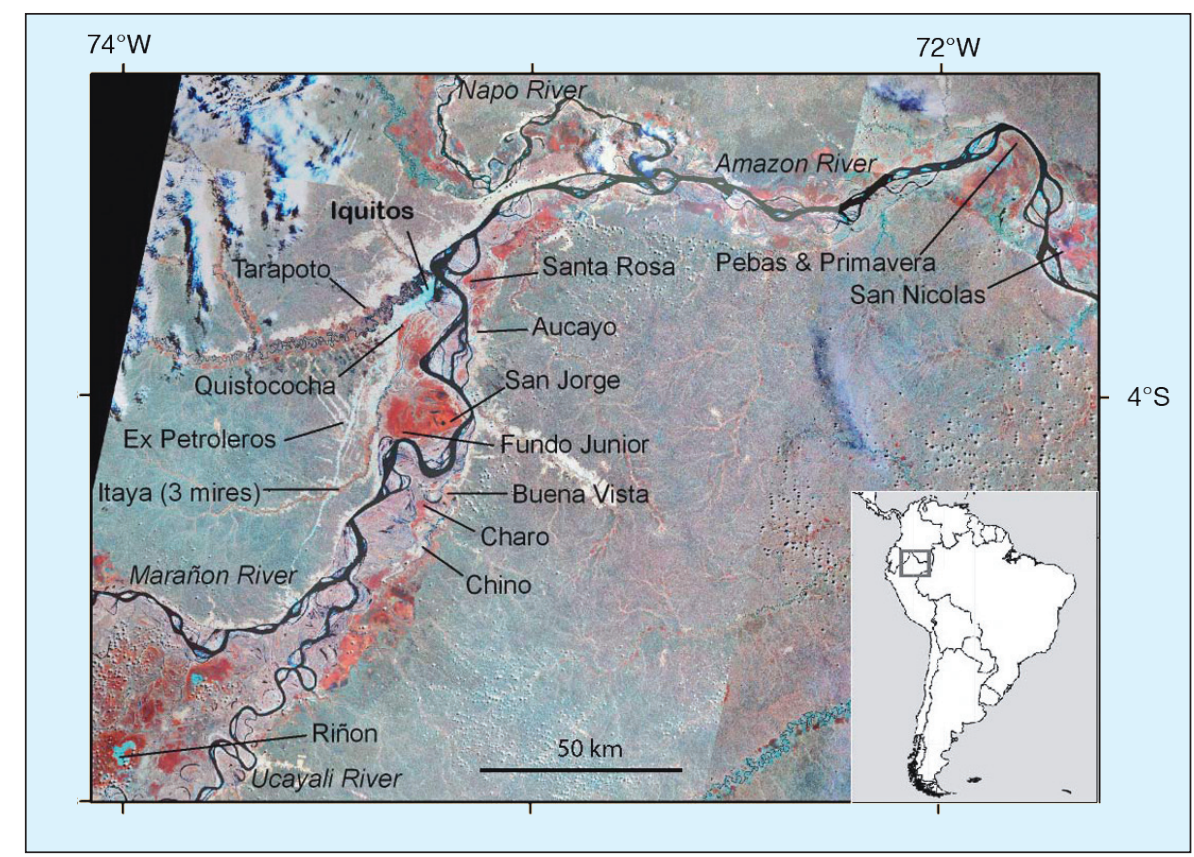

Figure 1: The location of the study sites (from Lähteenoja et al., 2009b, Fig. 1). The map is a mosaic of histogramequalized Landsat TM satellite images (WWw.glcf.umiacs.umd.edu/). Palm swamps and forested wetlands havea reddish tone, more or less treeless open areas (like the open peatland Riñón) are blue-green, and other floodplain forests are pinkish to white.

(Fig. 2) and therefore constitute a strong carbon sink (Lähteenoja et al., 2009b). These accumulation rates are comparable to those of the Indonesian tropical peatlands (Page et al., 2004) and are higher than those of the boreal peatlands (Tolonen and Turunen, 1996).

The basal ages of five dated peat deposits varied from $0.588 \mathrm{cal} \mathrm{ka} \mathrm{BP}$ (at 164 $\mathrm{cm}$ ) to $2.945 \mathrm{cal} \mathrm{ka} \mathrm{BP} \mathrm{(at} 565 \mathrm{~cm}$ ) (Lähteenoja et al., 2009b), which are considerably younger than basal ages determined in peatlands in many other regions of the world (cf., Korhola et al., 2010). There are several possible reasons for this. A paleoecological study of lake sediments in Peruvian Amazonia suggests that the dry conditions of the middle Holocene were followed by a period of increasingly wet conditions beginning some time between 4.2 and 2.54 cal ka BP (Bush et al., 2007). Although our oldest peat initiation dates coincide broadly with the onset of this wet interval, some of the peat deposits have much younger basal ages (Lähteenoja et al., 2009b), indicating that peat formation was not determined purely by climate. Peat initiation may be controlled by the dynamic lateral migration of western Amazonian rivers, characterized by meandering and avulsion (Kalliola et al., 1992; Neller et al., 1992; Pärssinen et al., 1996), which have the potential to erode and bury peat deposits. Peat accumulation probably began when an area with waterlogged conditions was isolated from the immediate destructive influence of rivers. Consequently, the Western Amazon Basin 


\section{S. Page, R. Wüst and C. Banks}

Anderson, J.A.R., 1983: The tropical peat swamps of western Malesia. In: Gore, A.J.P. (Ed.) Ecosystems of the World: Mires: Swamp, Bog, Fen and Moor, 4B, Regional Studies, Elsevier, New York: 181-199 pp.

Anderson, J.A.R. and Muller, J., 1975: Palynological study of a Holocene peat and a Miocene coal deposit from NW Borneo, Review of Paleobotany and Palynology, 19: 291-351.

Anshari, G., Kershaw, AP. and van der Kaars, S., 2001: A Late Pleistocene and Holocene pollen and charcoal record from peat swamp forest, Lake Sentarum Wildlife Reserve, West Kalimantan, Indonesia, Palaeogeography, Palaeoclimatology, Palaeoecology, 171: 213-228.

Anshari, G., Kershaw, A.P., Kaars, S.V.D. and Jacobsen, G., 2004: Environmental change and peatland forest dynamics in the Lake Sentarum area, West Kalimantan, Indonesia, Journal of Quaternary Science, 19: 637-655.

Brady, M.A., 1997: Organic matter dynamics of coastal peat deposits in Sumatra, Ph.D. Thesis, University of British Columbia, Vancouver, Canada.

Dam, R.A.C., Fluin, J., Suparan, P. and van der Kaars, S., 2001: Paleoenvironmental developments in the Lake Tondano area (N-Sulawesi, Indonesia) since 33,000 yr B.P., Palaeogeography, Palaeoclimatology, Palaeoecology, 171: 147-183.

Geyh, M.A., Kudrass, H.R. and Streif, H., 1979: Sea-level change during the late Pleistocene and Holocene in the Strait of Malacca, Nature, 278: 441-443.

Gorham, E., 1991: Northern peatlands: Role in the carbon cycle and probable responses to climatic warming, Ecological Applications, 1: 182-195.

Hesp, P.A., Cheng, C.H., Hilton, M., Chou, L.M. and Turner, I., 1998: A first tentative Holocene sea level curve for Singapore, Journal of Coastal Research, 14: 308-314.

Hooijer, A., Silvius, M., Wösten, H. and Page, S.E., 2006: PEAT-CO2, Assessment of $\mathrm{CO}_{2}$ emissions from drained peatlands in SE Asia, Delft Hydraulics report Q3943: 41.

Hu, J., Peng, P., Fang, D., Jia, G., Jian, Z. and Wang, P., 2003: No aridity in Sunda Land during the Last Glaciation: Evidence from molecular-isotopic stratigraphy of long-chain n-alkanes, Palaeogeography, Palaeoclimatology, Palaeoecology, 201: 269-281.

Immirzi, C.P. and Maltby, E. with Clymo, R.S., 1992: The Global Status of Peatlands and their Role in Carbon Cycling, A report for Friends of the Earth by the Wetland Ecosystems Research Group, Report 11, Department of Geography, University of Exeter, Exeter, UK, Friends of the Earth, London.

Kienast, M., Steinke, S., Stattegger, K. and Calvert, S.E. 2001: Synchronous tropical South China Sea SST change and Greenland warming during deglaciation, Science, 291: 21322134.

Kienast, M., Kienast, S.S., Calvert, S.E., Eglinton, T.I., Mollenhauer, G., Francois, R. and Mix, A.C. 2006: Eastern Pacific cooling and Atlantic overturning circulation during the last deglaciation, Nature, 443: 846-849.

Maloney, B.K. and McCormac, F.G., 1995: A 30,000-year pollen and radiocarbon record from Highland Sumatra as evidence for climatic change. Radiocarbon, 37: 181-190.

Maxwell, A.L., 2001: Holocene monsoon changes inferred from lake sediment pollen and carbonate records, northeastern Cambodia, Quaternary Research, 56: 390-400.

Maxwell, A.L. and Liu, K-B., 2002: Late Quaternary pollen and associated records from the monsoonal areas of continental South and SE Asia. In: Kershaw, A.P., Tapper, N.J., David, B., Bishop, P.M. and Penny, D. (Eds), Bridging Wallace's Line, Advances in GeoEcology 34, Catena Verlag, Reiskirchen: 189-228.

Morley R.J., 2000: Origin and Evolution of Tropical Rain Forests, Wiley, Chichester, Sussex.

Neuzil, S.G., 1997: Onset and rate of peat and carbon accumulation in four domed ombrogenous peat deposits, Indonesia. In: J.O. Rieley and S.E. Page (Eds), Biodiversity and Sustainable Management of Tropical Peatlands, Samara, Cardigan, UK: 55-72.

Page, S.E., Rieley, J.O., Shotyk, W. and Weiss, D., 1999: Interdependence of peat and vegetation in a tropical swamp forest, Philosophical Transactions of the Royal Society, B, 354: 1885-1897. 
Page, S.E., Siegert, F., Rieley, J.O., Boehm, H-D.V., Jaya, A. and Limin, S.H., 2002: The amount of carbon released from peat and forest fires in Indonesia during 1997, Nature, 420: $61-65$.

Page, S.E., Wüst, R.A., Weiss, D., Rieley, J.O., Shotyk, W. and Limin, S.H., 2004: A record of Late Pleistocene and Holocene carbon accumulation and climate change from an equatorial peat bog (Kalimantan, Indonesia): implications for past, present and future carbon dynamics, Journal of Quaternary Science, 19: 625-635.

Page, S.E., Rieley, J.O. and Wüst, R., 2006: Lowland tropical peatlands of Southeast Asia. In: Martini, P., Martinez-Cortizas, A. and Chesworth, W. (Eds) Peatlands: basin evolution and depository of records on global environmental and climatic changes, Elsevier, Amsterdam (Developments in Earth Surface Processes series): 145-172.

Page, S.E., Rieley, J.O. and Banks, C.J., in review: Extent and global significance of tropical peat carbon pools, Global Change Biology.

Penny, D., 2001: A 40,000 year palynological record from north-east Thailand; implications for biogeography and paleo-environmental reconstruction, Palaeogeography, Palaeoclimatology, Palaeoecology, 171: 97-128.

Rieley, J.O., Ahmad-Shah, A-A. and Brady, M.A., 1996: The extent and nature of tropical peat swamps. In: E. Maltby, C.P. Immirzi and Safford, R.J. (Eds.), Tropical Lowland Peatlands of Southeast Asia, IUCN, Gland, Switzerland: 17-53.

Sieffermann, G., Triutomo, S., Sadelman, M.T., Kristijono, A. and Parhadimulyo, S.A., 1987: The peat genesis in the lowlands of Central Kalimantan province, The respective influence of podzolisation and bad drainage, the two main processes of peat genesis in Kalimantan, International Peat Congress, Yogyakarta, ORSTOM, Yogyakarta: $17 \mathrm{pp}$.

Sieffermann, R.G., Fournier, M., Triutomo, S., Sadelman, M.T. and Semah, A.M., 1988: Velocity of tropical forest peat accumulation in Central Kalimantan province, Indonesia (Borneo). In: Proceedings of the 8th International Peat Congress, Leningrad, USSR, International Peat Society, Jyväskylä, Finland, 1: 90-98.

Sieffermann, R.G., Rieley, J.O. and Fournier, M., 1992: The lowland peat swamps of Central Kalimantan (Borneo): a complex and vulnerable ecosystem. In: Proceedings of the International Conference on Geography in the Asean Region, Yogyakarta, Indonesia: 22 pp.

Staub, J.R. and Esterle, J.S., 1994: Peat-accumulating depositional systems of Sarawak, East Malaysia, Sedimentary Geology, 89: 91-106.

Tjia, H.D., 1992: Holocene sea-level changes in the Malay-Thai Peninsula, a tectonically stable environment, Bulletin of the Geological Society of Malaysia, 31: 157-176.

Tjia, H.D., Sujitno, S., Suklija, Y., Harsono, R.A.F., Rachmat, A., Hainim, J. and Djunaedi, 1984: Holocene shorelines in the Indonesian Tin Islands, Modern Quaternary Research in SE Asia, 8: 103-117.

van der Kaars, W.A., Penny, D., Tibby, J., Fluin J., Dam R.A.C. and Suparan, P., 2001: Late Quaternary palaeoecology, palynology and palaeolimnology of a tropical lowland swamp: Rawa Danau, West Java, Indonesia, Palaeogeography, Palaeoclimatology, Palaeoecology, 171: 129-145.

van der Werf, G.R., et al., 2008: Climate regulation of fire emissions and deforestation in equatorial Asia, Proceedings of the National Academy of Sciences of the United States of America, 105: 20350-20355.

Wilford, G.E., 1959: Radiocarbon age determination of Quaternary sediments in Brunei and northeast Sarawak, British Borneo Geological Survey Annual Report 1959: 16-20.

Wüst, R.A.J. and Bustin, R.M., 2004: Late Pleistocene and Holocene development of the interior peat-accumulating basin of tropical Tasek Bera, Peninsular Malaysia, Palaeogeography, Palaeoclimatology, Palaeoecology, 211: 241-270.

Wüst, R.A.J., Rieley J., Page S., Kaars S.v.d., Wei-Ming W., Jacobsen G. and Smith A., 2007: Peatland evolution in Southeast Asia during the last 35,000 cal years: Implications for evaluating their carbon storage potential. In: J.O. Rieley, C.J. Banks and B. Radjagukguk (Eds), Carbon-climate-human Interaction on Tropical Peatland. Proceedings of The International Symposium and Workshop on Tropical Peatland, 
Yogyakarta, 27-29 August 2007, EU CARBOPEAT and RESTORPEAT Partnership,

Gadjah Mada University, Indonesia and University of Leicester, United Kingdom: 19. 